\title{
PENGARUH PENGENCER KUNING TELUR AYAM DENGAN AIR KELAPA MUDA TERHADAP INTEGRITAS MEMBRAN PLASMA DAN ABNORMALITAS SPERMATOZOA DOMBA SAPUDI
}

\section{THE INFLUENCE OF MIXTURE DILUTER OF CHICKEN EGG YOLK AND YOUNG COCONUT WATER ON THE INTEGRITY OF PLASMA MEMBRANE AND ABNORMALITIES OF SAPUDI SHEEP SPERMATOZOA}

\author{
Mayrena Ayu Cesaria $^{1)}$, A.T.Soelih Estoepangestie ${ }^{2)}$, *Suherni Susilowati ${ }^{3)}$, \\ Tatik Hernawati $^{4}$, Sri Pantja Madyawati ${ }^{5}$, Indah Norma Triana ${ }^{6}$ \\ ${ }^{1)}$ Student, ${ }^{2)}$ Veterinary Public Health of Veterinary Medicine, \\ $3,4,5,6)$ Department of Veterinary Reproduction \\ Faculty of Veterinary Medicine, Universitas Airlangga \\ *Corresponding author: email: suhernifkhunair@gmail.com; rere.ayucesaria16@gmail.com
}

\begin{abstract}
This study aimed to determine the influence of mixture diluter of chicken egg yolk and young coconut water on the integrity of plasma membrane and abnormalities of Sapudi sheep spermatozoa. The experimental design used in this study was a complete random method. The data was analysed using ANOVA, and if there is a significant difference then proceed with Duncan's Multiple Range Test ( DMRT ) at significance level of 5\%. Based on the result of the research, the influence of mixture diluter of chicken egg yolk and young coconut water was not significantly different $(\mathrm{p}>0,05)$ on the intact plasma membrane of spermatozoa on the first day until the fourth day. Interaction between treatment and storage duration had no effect on spermatozoa abnormality on the first day, second day and the fourth day. It can be concluded that mixture diluter of chicken egg yolk and young coconut water had a good effect on the plasma membrane and spermatozoa abnormalities up to the third day.

Keywords: young coconut water, chicken egg yolk, plasma membrane, abnormalities, sperm sapudi sheep
\end{abstract}

\section{Pendahuluan}

Domba Sapudi merupakan salah satu jenis ternak domba yang dimanfaatkan untuk dikembangkan sebagai pemenuhan kebutuhan protein hewani masyarakat Indonesia. Budidaya domba sapudi merupakan salah satu sumber daya genetik ternak Indonesia yang perlu dilestarikan keberadaannya, karena pada masing-masing daerah domba sapudi memiliki karakteristik yang spesifik dibandingkan daerah lain yang disebabkan karena perbedaan lingkungan, pola pemeliharaan dan akibat persilangan dengan domba luar atau inbreeding.

Dalam mengatasi permasalahan tersebut dilakukannya upaya dengan memperbaiki aspek teknologi reproduksinya pada Inseminasi Buatan ( IB ). Untuk menunjang keberhasilan program IB maka harus disertai penggunaan semen yang berkualitas, karena keberhasilan IB akan mempengaruhi fertilitas. Jenis pengencer yang dapat digu- nakan untuk mengamati integritas membran plasma dan abnormalitas spermatozoa domba sapudi adalah air kelapa muda dan kuning telur ayam.

Air kelapa muda dan kuning telur ayam mempunyai sumber nutrisi untuk metabolisme spermatozoa, mempunyai sifat isotonic terhadap semen, mempunyai sifat sebagai buffer, dapat melindungi spermatozoa dalam proses pendinginan, dan mempunyai efek anti bakteri dan tidak boleh mengandung zat-zat yang bersifat toksik atau racun. Penelitian ini bertujuan untuk mengetahui pengaruh pemberian komposisi kuning telur ayam dan air kelapa muda yang berfungsi untuk melindungi dalam mempertahankan integritas selubung lipoprotein dari sel dan mencegah cekaman dingin maupun pembekuan. 


\section{Metode Penelitian}

Penelitian ini bertempat di Laboratorium Reproduksi Ternak Fakultas Kedokteran Hewan, Universitas Airlangga untuk pemeriksaan kualitas semen. Sampel penelitian yang digunakan adalah semen yang diperoleh dari penampungan satu ekor domba Sapudi jantan, berumur \pm 4 tahun yang secara klinis dinyatakan sehat karena memiliki alat kelamin normal dan libido yang baik. Penampungan semen dilakukan 2 kali dalam satu minggu yang dibagi ke dalam satu kontrol, empat perlakuan dan empat ulangan.

Pada penelitian ini semen yang telah diencerkan dengan air kelapa muda dan kuning telur ayam ditambahkan larutan HOST untuk mengukur apakah membran plasma masih aktif atau tidak serta sebagai indikator keberhasilan fertilisasi.

Air kelapa muda dan kuning telur ayam pada semen yang telah diencerkan dan ditambahkan larutan HOST dimasukkan pada satu kontrol dan empat perlakuan dengan dosis pengencer air kelapa muda dan kuning telur ayam yang berbeda dengan P0 (semen domba $0,1 \mathrm{ml}+1 \mathrm{ml}$ kuning telur), P1 (semen domba 0,1 ml + 0,9 ml kuning telur + 0,1 ml air kelapa muda), P2 (semen domba $0,1 \mathrm{ml}+0,8 \mathrm{ml}$ kuning telur $+0,2$ ml air kelapa muda), P3 (semen domba 0,1 $\mathrm{ml}+0,7 \mathrm{ml}$ kuning telur $+0,3 \mathrm{ml}$ air kelapa muda), P4 (seemen domba $0,1 \mathrm{ml}+0,6 \mathrm{ml}$ kuning telur $+0,4 \mathrm{ml}$ air kelapa muda), setelah pengenceran selesai dibuat dan se- belum air mani dicampurkan, ditambahkan antibiotik Peniciline 1000 IU dan Streptomycine $1 \mathrm{mg}$ dalam $1 \mathrm{cc}$ pengencer, masing-masing dicampur dan diaduk hingga rata, diulang sebanyak empat kali.

\section{Pemeriksaan Membran Plasma Utuh Spermatozoa Domba Sapudi}

Data persentase abnormalitas spermatozoa domba sapudi dari kontrol, empat perlakuan dengan pengencer air kelapa muda dan kuning telur ayam dan empat kali ulangan yang tercantum pada Tabel 1 .

Setelah pengenceran selesai dibuat dan sebelum air mani dicampurkan ditambahkan antibiotic Peniciline 1000 IU dan Streptomycine $1 \mathrm{mg}$ dalam $1 \mathrm{cc}$ pengencer, masing-masing dicampur dan diaduk hingga rata (Susilowati dkk., 2010).

Dari hasil pengamatan membran plasma utuh spermatozoa pada penelitian untuk kontrol (P0) dan empat macam perlakuan (P1, P2, P3, P4) pada hari pertama dianalisis dengan menggunakan uji ANOVA dan dilanjutkan menggunakan uji Duncan. Untuk pemeriksaan hari kedua sampai dengan keempat dianalisis dengan uji ANOVA.

Berdasarkan teori larutan yang osmolaritasnya $100 \mathrm{mOsm} / \mathrm{L}$ menunjukkan angka terbesar untuk melihat pembengkakan spermatozoa. Spermatozoa yang bengkok pada bagian ekornya lebih dari $60 \%$ pada larutan HOST Test pada tekanan osmotik

Tabel 1. Rata-rata dan Standart Deviasi Persentase Membran Plasma Utuh Spermatozoa Domba Sapudi

\begin{tabular}{ccccc}
\hline \multirow{2}{*}{ Perlakuan } & \multicolumn{4}{c}{$\begin{array}{c}\text { Membran Plasma Utuh Spermatozoa (\%) } \\
\text { ( Rerata } \pm \text { Standart Deviasi ) }\end{array}$} \\
& Hari Pertama & Hari Kedua & Hari Ketiga & Hari Keempat \\
\hline Kontrol (P0) & $71,69^{\mathrm{a}} \pm 1,96$ & $64,20^{\mathrm{a}} \pm 1,26$ & $56,48^{\mathrm{ab}} \pm 3,01$ & $48,59^{\mathrm{a}} \pm 3,43$ \\
P1 & $71,18^{\mathrm{a}} \pm 0,82$ & $64,84^{\mathrm{a}} \pm 1,06$ & $56,33^{\mathrm{ab}} \pm 0,79$ & $47,34^{\mathrm{a}} \pm 0,82$ \\
P2 & $71,61^{\mathrm{a}} \pm 1,41$ & $63,85^{\mathrm{a}} \pm 1,76$ & $57,89^{\mathrm{b}} \pm 1,64$ & $50,27^{\mathrm{a}} \pm 0,41$ \\
P3 & $70,49^{\mathrm{a}} \pm 1,04$ & $63,09^{\mathrm{a}} \pm 2,21$ & $56,36^{\mathrm{a}} \pm 2,54$ & $47,82^{\mathrm{a}} \pm 3,26$ \\
P4 & $70,95^{\mathrm{a}} \pm 0,42$ & $62,78^{\mathrm{a}} \pm 0,88$ & $54,55^{\mathrm{a}} \pm 2,00$ & $48,95^{\mathrm{a}} \pm 0,42$ \\
\hline
\end{tabular}

Superskrip yang sama pada kolom yang sama menunjukkan tidak adanya perbedaan yang nyata $(\mathrm{p}>0,05)$

Keterangan: P0 : Semen domba $0,1 \mathrm{ml}+1 \mathrm{ml}$ kuning telur

$\mathrm{P} 1$ : Semen domba $0,1 \mathrm{ml}+0,9 \mathrm{ml}$ kuning telur $+0,1 \mathrm{ml}$ air kelapa muda

$\mathrm{P} 2$ : Semen domba $0,1 \mathrm{ml}+0,8 \mathrm{ml}$ kuning telur $+0,2 \mathrm{ml}$ air kelapa muda

$\mathrm{P} 3$ : Semen domba $0,1 \mathrm{ml}+0,7 \mathrm{ml}$ kuning telur $+0,3 \mathrm{ml}$ air kelapa muda

$\mathrm{P} 4$ : Semen domba $0,1 \mathrm{ml}+0,6 \mathrm{ml}$ kuning telur $+0,4 \mathrm{ml}$ air kelapa muda 
sebesar $100 \mathrm{mOsm} / \mathrm{L}$. Pada tabel 1 dapat dilihat bahwa rerata persentase membran plasma utuh spermatozoa domba Sapudi pada saat penyimpanan hari pertama, hari kedua, hari ketiga, dan hari keempat hasil yang paling tinggi yaitu hari pertama perlakuan P0.

Hasil pengamatan ini sesuai dengan hasil penelitian yang dinyatakan oleh (Aboagla dan Terada, 2004) bahwa bahan anti cold shock yang umum ditambahkan adanya kuning telur yang dapat melindungi spermatozoa pada saat perubahan suhu dari suhu ruang pada saat pengolahan ke suhu ekuilibrasi. Solihati dan Kune ( 2009 ) menyatakan setiap bahan pengencer yang baik dapat memperlihatkan kemampuannya dalam memperkecil gerak progresif sperma sehingga dapat memperpanjang waktu lama penyimpanan pasca pengenceran.

Penelitian ini menunjukkan bahwa kualitas semen yang diamati pada hari pertama sampai dengan hari keempat terjadi penurunan membran plasma spermatozoa, yang disebabkan faktor adanya cold shock yang terjadi karena penurunan suhu secara mendadak yang bisa mencapai dibawah $0^{\circ} \mathrm{C}$, seperti dinyatakan oleh Siti ( 2012 ) disebabkan dalam tahap transisi dari mem-bran lipid sehingga terjadinya pemisahan dan penurunan sifat permeabilitas dari mem-bran biologi sel hidup. Menurut Gazali dan Tambing ( 2002 ) menyatakan bahwa penumpukan elektrolit merusak dinding membran sel sehingga pada waktu pencairan kembali membrane plasma akan menurun dan sel akan mati.

\section{Pemeriksaan Abnormalitas Sperma- tozoa}

Data persentase abnormalitas spermatozoa domba sapudi dari kontrol, empat perlakuan dengan pengencer air kelapa muda dan kuning telur ayam dan empat kali ulangan yang tercaantum pada Tabel 2 .

Salah satu indikator yang menentukan kualitas spermatozoa adalah abnormalitas karena pada struktur sel abnormal dapat menyebabkan oleh gangguan maupun hambatan pada saat fertilisasi. Hasil uji ANOVA abnormalitas spermatozoa domba Sapudi pada pengencer air kelapa muda dan kuning telur ayam bahwa tidak ada perbedaan nyata $(p>0,05)$ dari hari pertama, hari kedua, dan hari keempat pada setiap perlakuan. Hal ini menunjukkan bahwa pengencer air kelapa muda dengan kuning telur ayam tidak berpengaruh pada abnormalitas spermatozoa domba sapudi, karena di dalam pengencer mengandung zat-zat pelindung yang berfungsi untuk menjaga osmolaritas larutan dan integritas struktur spermatozoa.

Sesuai yang dinyatakan oleh Qomariyah dkk. ( 2001 ) bahwa lipoprotein dan lesitin yang terdapat pada kuning telur mampu melindungi keutuhan selubung lipoprotein. Pada hasil penelitian menunjukkan bahwa pengencer air kelapa muda dan kuning telur masih mampu untuk menjaga spermatozoa sehingga masih layak untuk digunakan inseminasi buatan. Hasil pengamatan abnormalitas spermatozoa domba Sapudi pada tabel 4.4 menunjukkan hasil tertinggi waktu penyimpanan yaitu pada hari keempat pelakuan P0. Pada hari ketiga untuk perlakuan P4 memberikan perbedaan yang signifikan $(\mathrm{P}<0,05$ ) terhadap abnormalitas spermatozoa domba Sapudi. Hal ini sesuai dengan pendapat Garner dan Hafez ( 2000 ) bahwa kisaran abnormalitas spermatozoa domba antara 5$20 \%$, sehingga dilihat dari hasil penelitian maka nilai abnormal spermatozoa masih bawah batas normal.

\section{Kesimpulan}

Berdasarkan dari hasil penelitian dan pembahasan dari penelitian penga-ruh pengencer air kelapa muda dan kuning telur ayam terhadap integritas membran plasma dan abnormalitas sper-matozoa domba sapudi dapat ditarik ke-simpulan sebagai berikut :

1. Kombinasi pengencer air kelapa muda dan kuning telur ayam dapat mempertahankan integritas membran plasma utuh spermatozoa domba Sapudi.

2. Kombinasi pengencer air kelapa muda dan kuning telur ayam dapat menurunkan terhadap abnormalitas spermatozoa domba Sapudi.

\section{Daftar Pustaka}

Aboagla EM-, Terada T. 2004a. Effects of egg yolk during the freezing step of cryopreservation on the viability of goat spermatozoa. Theriogenology. 62:1160-1172. 
Tabel 2 Rata-rata dan Standart Deviasi Persentase Abnormalitas Spermatozoa Domba Sapudi

\begin{tabular}{ccccc}
\hline \multirow{2}{*}{ Perlakuan } & \multicolumn{4}{c}{ Abnormalitas Spermatozoa (\%) } \\
& HariPertama & Hari Kedua & Hari Ketiga & Hari Keempat \\
\hline Kontrol (P0) & $17,29^{\mathrm{b}} \pm 1,59$ & $15,52^{\mathrm{a}} \pm 2,40$ & $17,22^{\mathrm{b}} \pm 1,61$ & $20,57^{\mathrm{b}} \pm 1,00$ \\
P1 & $13,63^{\mathrm{ab}} \pm 1,81$ & $15,05^{\mathrm{a}} \pm 1,01$ & $17,61^{\mathrm{b}} \pm 0,95$ & $19,83^{\mathrm{ab}} \pm 2,04$ \\
P2 & $13,73^{\mathrm{ab}} \pm 3,32$ & $15,49^{\mathrm{a}} \pm 2,87$ & $16,61^{\mathrm{b}} \pm 1,00$ & $18,90^{\mathrm{ab}} \pm 2,54$ \\
P3 & $13,59^{\mathrm{ab}} \pm 1,14$ & $14,87^{\mathrm{a}} \pm 1,66$ & $16,34^{\mathrm{b}} \pm 1,22$ & $19,91^{\mathrm{ab}} \pm 1,23$ \\
P4 & $13,45^{\mathrm{a}} \pm 2,92$ & $13,05^{\mathrm{a}} \pm 2,09$ & $14,19^{\mathrm{a}} \pm 2,00$ & $17,38^{\mathrm{a}} \pm 1,98$ \\
\hline
\end{tabular}

Superskrip yang sama pada kolom yang sama menunjukkan tidak adanya perbedaan yang nyata $(\mathrm{p}>0,05)$

Keterangan : P0 : Semen domba $0,1 \mathrm{ml}+1 \mathrm{ml}$ kuning telur P1: Semen domba $0,1 \mathrm{ml}+0,9 \mathrm{ml}$ kuning telur $+0,1 \mathrm{ml}$ air kelapa muda $\mathrm{P} 2$ : Semen domba $0,1 \mathrm{ml}+0,8 \mathrm{ml}$ kuning telur $+0,2 \mathrm{ml}$ air kelapa muda $\mathrm{P} 3$ : Semen domba $0,1 \mathrm{ml}+0,7 \mathrm{ml}$ kuning telur $+0,3 \mathrm{ml}$ air kelapa muda $\mathrm{P} 4$ : Semen domba $0,1 \mathrm{ml}+0,6 \mathrm{ml}$ kuning telur $+0,4 \mathrm{ml}$ air kelapa muda

Ajiardiana, I.A. 2015. Pengaruh Penambahan Plasma Seminalis Sapi Simmental Terhadap Membran Plasma Utuh dan Nekrosis Spermatozoa DEG Setelah Ekuilibrasi Pada Proses Pembekuan. Skripsi. Fakultas Kedokteran Hewan. Universitas Airlangga.

Barlina, R. 2004. Potensi Buah Kelapa Muda Untuk Kesehatan Dan Pengolahannya. Balai Penelitian Tanaman Kelapa Dan Palma Lain. Manado.

Faizal, M. 2016. Pengaruh Penggunaan Kuning Telur Angsa (Cignus olor) Dan Air Kelapa Muda (Cocos nutifera) Terhadap Kualitas Sperma Kambing Boer Dengan Waktu Equilibrasi Yang Berbeda. Jurusan Biologi Fakultas Sains Dan Teknologi. Universitas Islam Negeri Maulana Malik Ibrahim. Malang.

Garner DL and Hafez ESE. 2000. Spermatozoa and seminal plasma. Di dalam : Hafez B, Hafez ESE, editor. Reproduction in Farm Animal. Ed ke-7. Philadelphia: Lippincot William and Wilkins. Chapter 7. 96-109

Gazali M, dan S.N. Tambing. 2002. Kriopreservasi sel spermatozoa. Hayati. 9(1); 27-32.

Hariadi. M, AS. Hardjopranyoto, Wurlina, H.A. Hermadi, B. Utomo, Rimayanti, I.N. Triana dan H. Ratnani. 2011. Ilmu Kemajiran pada Ternak. Airlangga University Press. Surabaya.

Men' Health. 2015. Kandungan Gizi Air Kelapa.http://www.menshealth.co.id/n utrisi.umum/ kandungan. gizi air. kelapa/ 003/002/138. Diakses pada tanggal 10 April 2014.

Payung, R. 2015. Pengaruh Perbedaan Komposisi Kuning Telur Itik dan Air Kelapa Muda Sebagai Pengencer Semen Terhadap Kualitas Spermatozoa Sapi Bali Pasca Thawing Di Unit Pelaksana Teknis Daerah Inseminasi Buatan Pucak Kabupaten Maros. Skripsi. Fakultas Kedokteran Hewan. Universitas Hasanuddin. Makassar.

Qomariyah, S. Mihardja, dan R. Idi. 2001. Pengaruh kombinasi kuning telur dengan air kelapa terhadap daya tahanhidup dan abnormalitas spermatozoa domba Priangan pada penyimpanan $5^{\circ} \mathrm{C}$. Seminar Nasional Teknologi Peternakan dan Veteriner.

Siti A. 2012. Karakteristik Spermatozoa Domba Selama Proses Pembekuan Dengan Medium Pengencer Yang Ditambahkan Glutation. Fakultas Kedokteran Hewan Institut Pertanian Bogor. Bogor.

Solihati, N. 2008. Studi Terhadap Kualitas Dan Daya Tahan Hidup Spermatozoa Cauda Epididimis Domba Garut Menggunakan Berbagai Jenis Pengencer. Seminar Nasional Teknologi Peternakan dan Veteriner. Fakultas Peternakan Universitas Padjadjaran. Bandung.

Suryaningsih, H. 2016. Penambahan LArginin Dalam Pengencer Tris Kuning Telur Setelah Ekuilibrasi 1 Jam Terhadap Motilitas Dan Membran Plasma Utuh Spermatozoa Domba Ekor Gemuk. Skripsi. Fakultas Kedokteran 
Hewan. Universitas Airlangga. Surabaya.

Susilowati, S., Hardijanto, T.W. Suprayogi, T. Sardjito, dan T. Hernawati. 2010. Penuntun Praktikum Inseminasi Buatan. Fakultas Kedokteran Hewan. Universitas Airlangga. Surabaya.
Wibowo, A. 2015. Koleksi Semen Dan Pemeriksaan Kualitas Semen. Fakultas Pertanian Universitas Lampung. 